\title{
APENDECTOMY; COMPARISON OF OUTCOME IN OPEN AND LAPAROSCOPIC APENDECTOMY
}

1. MBBS, FCPS

Senior Registrar, S-2

Allied Hospital, Faisalabad

2. MBBS

Medical Officer

Allied Hospital, Faisalabad

3. MBBS, FCPS

Senior Registrar, S-3

Allied Hospital, Faisalabad

Correspondence Address:

Dr. Ahmad Raees

Medical Officer

Allied Hospital, Faisalabad

ahmadbajwa2009@gmail.com

Article received on:

06/03/2017

Accepted for publication:

21/04/2017

Received after proof reading: 06/05/2017

\section{Dr. Abdullah Bin Saeed', Dr. Ahmad Raees ${ }^{2}$, Dr. Shoukat Ali ${ }^{3}$}

ABSTRACT... Introduction: Appendicitis is one of the most common cause of an acute abdomen in young adults. Open appendectomy (OA) has been the gold standard for the treatment of acute appendicitis since its introduction by Charles McBurney in 1889.Laproscopic appendectomy (LA) was first performed by Semn in 1983.After its introduction laparoscopic appendectomy (LA) proved to be a feasible and safe procedure. Objective: To compare the outcome of Open appendectomy and Laparoscopic appendectomy in terms of mean visual analogue score of postoperative pain and mean operative duration in the treatment of acute appendicitis. Study Design: Randomized clinical trial. Setting: Punjab Medical College and affiliated Hospitals, Faisalabad. Duration: Study was carried out for one year from 01-01-2016 to 31-12-2016. Subjects and Method: A total of 70 patients with Appendicitis were included in the study. All patients were diagnosed clinically and confirmed with Laboratory findings. 35 patients underwent open appendectomy and laparoscopic appendectomy was used in 35 . Outcome in terms of pain and operating time was compared in both groups. Results: Mean age in group A was 27.74 years with a standard deviation of 12.040 . Mean age of patients in group B was 29.26 years with a standard deviation of 12.650. Post-Operative pain using Visual Analog Scale was $7.34 \pm 2.014$ in group $A$ and $3 \pm 1.94$ in group B. Operative duration in group $A$ was $42.33 \pm 4.25$ (minutes) and group $B$ had a duration of $34.48 \pm 3.5$ (minutes). Conclusion: Outcome of Laparoscopic appendectomy is better than open appendectomy in terms of pain and operative duration in patients undergoing Appendectomy.

Key words: $\quad$ Appendicitis, Laparoscopic appendectomy, Open appendectomy

Article Citation: Saeed AB, Raees A, Ali S. Apendectomy; Comparison of outcome in open and laparoscopic apendectomy. Professional Med J 2017;24(5):690-696. DOI: 10.17957/TPMJ/17.3919

\section{INTRODUCTION}

Inflammation of appendix known as appendicitis in one of the most important and common cause of acute abdomen in all age groups including young adults. ${ }^{1}$ According to researches and data analysis on large scale 8.6 out of 100 males and 6.7 out of 100 females have a life time risk to develop acute appendicitis. ${ }^{2}$ As the term denotes acute appendicitis is a medical emergency which require prompt treatment with appendectomy which can be performed either by open appendectomy introduced by charles Mcburney in 1889 or by Laparoscopic appendectomy which is relatively a newer technique introduced in 1983 by semen. ${ }^{2}$ As with other procedures undergone by laparoscopy, laparoscopic appendectomy gained attention due to its safety and Expediency and is accepted worldwide. ${ }^{3}$.
Recent advances in endoscopy has opened new windows of performing laparoscopic appendectomy with some studies claiming superiority of laparoscopic appendectomy over conventional open appendectomy due to less pain post operatively, quicker recovery due to less tissue handling and small incision, less post operative complications and early return to normal daily activities and good cosmetic results. Among all these Post Operative Pain reduction is one of the most important considered factor in favor of laparoscopic surgery. As shown by studies overall post-operative pain was significantly less in patients of laparoscopic group as compared to open appendectomy with mean post operative pain according to visual analogue score at 48 hours of laparoscopic appendectomy is $1.5+-0.6$ and $4.6+-0.8$ for open appendectomy $(P=0.004){ }^{5,6}$ 
Another school of thoughts consider laparoscopic appendectomy have some set back like it may increase cost of treatment due to special equipments and instruments and large intraoperative time. A study designed to assess mean operative duration for laparoscopic and open appendectomy it was found that laparoscopic appendectomy has mean operative duration of 48.26+-12.02 minutes and open appendectomy have mean operative duration of $31.36+-$ 11.43 minutes $(p<0.001) .{ }^{6}$ This is currently not accepted $^{6}$ as it was proved in later studies that lack of experience and training in field of laparoscopy was the main reason behind increase intra operative time in laparoscopic group. A study conducted recently mean operative time for laparoscopic appendectomy was found to be 52.2 minutes (range 20-155) and 49.3 minutes (range 20-110) for open appendectomy group $(p=0.476){ }^{6}$

The rationale of this study is to provide guidelines to future surgeons to use Laparoscopic appendectomy as common procedure because this procedure is not commonly used in our setup due to fear of increased duration as shown by previous studies. ${ }^{5,6}$ Laparoscopic appendectomy for acute appendicitis may be suggested to be used more often in future if the results of this study show relative benefits.

\section{MATERIALS AND METHODS}

\section{Study design}

Randomized controlled trial.

\section{Study setting}

Punjab Medical College and affiliated Hospitals, Faisalabad.

\section{Study duration}

The study is carried out for one year from 01-012016 to $31-12-2016$

\section{Sampling technique}

Non-probability consecutive sampling.

\section{Sample size}

By using WHO sample size calculator for two means anticipated population mean $=48.26$, test value of population mean $=31.36$, pooled standard deviation $=12.14$, Level of significance $=5 \%$, Power of study $=90 \%$ and sample size $=70$ (35 in each group).

\section{SAMPLE SELECTION}

Inclusion criteria

All patients were included from 13 years of age to 60 years of either gender having clinical diagnosis of acute appendicitis. (as per operational definition)

\section{EXCLUSION CRITERIA}

1. Patients with chronic pain

2. Preoperative use of analgesics for $>3$ times per week for $>3$ months

3. Patient having absolute and relative contra indications for laparoscopic surgery.

Postoperative pain was noted and scored at 48 hours after surgery in the ward by each patient on a visual analogue scale (VAS) . The operative time in minutes was counted from time of skin incision given to last skin stitch applied in both Open appendectomy and Laparoscopic appendectomy. All the information was recorded on Performa. Data was analyzed by SPSS computer software version-20.

Outcome of Laproscopic appendectomy versus Open appendectomy will be measured in terms of following variables

1. Post-Operative Pain: It will be analyzed by visual analogue score at 48 hours without opioid analgesics. (Figure:1)

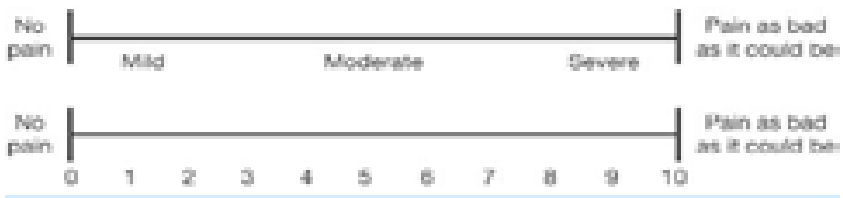

Figure-1. Visual analogue pain scale

2. Mean Operative Duration: The operative time in minutes will be counted from time of skin incision given to the last skin stitch applied in both Open appendectomy and Laproscopic appendectomy. 


\section{RESULTS}

70 patients (35 in each group) were taken during the study period one year from 01-01-2016 to 31-12-2016.

Minimum age was 13 years and maximum age was 59 years with a mean of 28.50 years and standard deviation of 12.283 (Table-I).

Mean age in group $A$ was 13 years with a standard deviation of 12.040. Mean age of patients in group B was 14 years with a standard deviation of 12.650. (Table-II)

In group A $31.4 \% \%$ of the patients were males and $68.6 \%$ patients were females. While in group B $60.0 \%$ patients were males and $40.0 \%$ of the patients were females. (Table-III)

$35.7 \%$ of patients in both groups were between 13-22 years. $35.7 \%$ of patients in both groups were between $23-32$ years. $12.9 \%$ of patients in both groups were between $33-42$ and $10.0 \%$ were between $43-52$ years and 5.7\% were above 52
(Table-IV).

Post-Operative pain using Visual Analogue Scale was $7.34 \pm 2.014$ in group $A$ and $3 \pm 1.94$ in group $B$. Operative duration in group $A$ was $42.33 \pm 4.25$ and group $B$ had a duration of $34.48 \pm 3.5$. (Table-V)

Male patients in group A had a pain of $7.36 \pm 1.63$ while the males in group $B$ had a pain score of 3.52 \pm 2.11 . Males in Group A had operative duration of $44.26 \pm 3.09$ and in group $B$ they had operative duration of $34.89 \pm 3$.9. There was statistically significant difference between the two with $P$ value of 0.001 . Female patients in group A had a pain of $7.33 \pm 2.2$ while the females in group $B$ had a pain score of $2.21 \pm 1.37$. Females in Group A had operative duration of $41.44 \pm 4.46$ and in group $B$ they had operative duration of 33.87 \pm 2.83 . There was statistically significant difference between the two with $\mathrm{P}$ value of 0.001 . (Table-VI)
Patient age

n

70

Minimum

13
Maximum

59
Mean
28.50
Std. Deviation

12.283

Table-I. Descriptive Statistics of Age

\begin{tabular}{|l|l|l|c|c|c|c|}
\hline Surgical Approach & N & Minimum & Maximum & Mean & Std. Deviation \\
\hline Open Appendectomy & patient age & 35 & 13 & 59 & 27.74 & 12.040 \\
\hline Laparoscopic Appendectomy & patient age & 35 & 14 & 59 & 29.26 & 12.650
\end{tabular}

Table-II. Descriptive statistics in each group

\begin{tabular}{|c|c|c|c|c|c|c|}
\hline & \multicolumn{4}{|c|}{ Surgical Approach } & \multirow{2}{*}{ Total } \\
\hline & & \multicolumn{2}{|c|}{ Open Appendectomy } & \multicolumn{2}{|c|}{ Laparoscopic Appendectomy } & \\
\hline \multirow{5}{*}{ Age distribution } & $13-22$ years & \multicolumn{2}{|l|}{$14(40.0 \%)$} & \multicolumn{2}{|l|}{$11(31.4 \%)$} & 25 (35.7\%) \\
\hline & 23-32 years & \multicolumn{2}{|l|}{$12(34.3 \%)$} & \multicolumn{2}{|l|}{$13(37.1 \%)$} & 25 (35.7\%) \\
\hline & $33-42$ years & \multicolumn{2}{|l|}{$4(11.4 \%)$} & \multicolumn{2}{|l|}{$5(14.3 \%)$} & $9(12.9 \%)$ \\
\hline & $43-52$ years & \multicolumn{2}{|l|}{$3(8.6 \%)$} & \multicolumn{2}{|l|}{$4(11.4 \%)$} & $7(10.0 \%)$ \\
\hline & \multirow{2}{*}{$\begin{array}{l}>52 \text { years } \\
\text { otal }\end{array}$} & \multicolumn{2}{|l|}{$2(5.7 \%)$} & \multicolumn{2}{|l|}{$2(5.7 \%)$} & $4(5.7 \%$ \\
\hline Total & & \multicolumn{2}{|l|}{35} & 35 & & 70 \\
\hline \multicolumn{7}{|c|}{$\begin{array}{l}\text { Table-III. Gender Distribution in Each Group } \\
\text { Chi-square value }=0.654 \quad p \text {-value }=0.95\end{array}$} \\
\hline & & \multicolumn{3}{|c|}{ Surgical Approach } & \multirow{2}{*}{\multicolumn{2}{|c|}{ Total }} \\
\hline & & Open Appendectomy & Lapr & sccopic Appendectomy & & \\
\hline \multirow{2}{*}{ Patient Sex } & Male & $11(31.4 \%)$ & & $21(60.0 \%)$ & & $2(45.7 \%)$ \\
\hline & Female & $24(68.6 \%)$ & & $14(40.0 \%)$ & & 8 (54.3\%) \\
\hline \multicolumn{2}{|c|}{ Total } & 35 & & 35 & & 70 \\
\hline
\end{tabular}




\begin{tabular}{|l|c|c|c|}
\hline \multirow{2}{*}{ Variables } & \multicolumn{3}{|c|}{ Surgical Approach } \\
\hline & Open Appendectomy $\mathbf{( n = 3 5 )}$ & Laparoscopic Appendectomy (n=35) & p-value \\
\hline Post-Operative pain & $7.34 \pm 2.014$ & $3 \pm 1.94$ & 0.0001 \\
\hline Operative duration & $42.33 \pm 4.25$ & $34.48 \pm 3.5$ & 0.0001 \\
\hline
\end{tabular}

Table-V. Variables in each group

\begin{tabular}{|l|l|c|c|c|}
\hline \multirow{2}{*}{ Gender } & \multicolumn{1}{|c|}{ Variables } & $\begin{array}{c}|c| \\
\text { Open Appendectomy } \\
\text { (n=35) }\end{array}$ & $\begin{array}{c}\text { Laparoscopic Appendectomy } \\
(\mathbf{n = 3 5 )}\end{array}$ & p-value \\
\hline \multirow{2}{*}{ Male } & Post-operative pain & $7.36 \pm 1.63$ & $3.52 \pm 2.11$ & 0.0001 \\
\cline { 2 - 5 } & Operative duration & $44.26 \pm 3.09$ & $34.89 \pm 3.9$ & 0.0001 \\
\hline \multirow{2}{*}{ Female } & Post-operative pain & $7.33 \pm 2.2$ & $2.21 \pm 1.37$ & 0.0001 \\
\cline { 2 - 5 } & operative duration & $41.44 \pm 4.46$ & $33.87 \pm 2.83$ & 0.0001 \\
\hline
\end{tabular}

Table-VI. Comparison of both the variables Between Two Groups according to Gender

\begin{tabular}{|c|c|c|c|c|}
\hline \multirow[b]{2}{*}{$\begin{array}{c}\text { Age } \\
\text { distribution }\end{array}$} & \multirow[b]{2}{*}{ Variables } & \multicolumn{2}{|c|}{ Surgical Approach } & \multirow[b]{2}{*}{ p-value } \\
\hline & & $\begin{array}{l}\text { Open Appendectomy } \\
(\mathrm{n}=35)\end{array}$ & $\begin{array}{l}\text { Laparoscopic Appendectomy } \\
\qquad(\mathrm{n}=35)\end{array}$ & \\
\hline \multirow[t]{2}{*}{$13-22$ years } & Postoperative pain & $7.57 \pm 1.45$ & $3.09 \pm 2.3$ & 0.0001 \\
\hline & operative duration & $44.18 \pm 4.45$ & $35.54 \pm 4.1$ & 0.0001 \\
\hline \multirow{2}{*}{ 23-32 years } & Postoperative pain & $6.5 \pm 2.58$ & $3 \pm 1.91$ & 0.001 \\
\hline & operative duration & $41.33 \pm 3.98$ & $33.99 \pm 3.64$ & 0.0001 \\
\hline \multirow{2}{*}{ 33-42 years } & Postoperative pain & $8.75 \pm 1.26$ & $3.6 \pm 2.3$ & 0.005 \\
\hline & Operative duration & $40.19 \pm 5.05$ & $33.49 \pm 2.81$ & 0.38 \\
\hline \multirow{2}{*}{ 43-52 years } & Postoperative pain & $7.67 \pm 1.16$ & $2.25 \pm 1.26$ & 0.002 \\
\hline & Operative duration & $40.33 \pm 2.53$ & $33.21 \pm 2.56$ & 0.015 \\
\hline \multirow{2}{*}{$>52$ years } & Postoperative pain & $7.5 \pm 3.53$ & $2.5 \pm 0.71$ & 0.189 \\
\hline & Operative duration & $42.55 \pm 1.41$ & $36.83 \pm 0.7$ & 0.065 \\
\hline \multicolumn{5}{|c|}{ Table-VII. Comparison of both the variables in two groups according to Age } \\
\hline
\end{tabular}

Studies conducted in recent years show laparoscopy as an important procedure to diagnose and treat abdominal emergencies reducing cost and invasiveness of procedure and improving outcomes. Several studies show that laparoscopic appendectomy is safer and result in fast return to normal activities, with very few postoperative complications. ${ }^{7,8}$ These studies were denounced by some other studies conducted by authors who contemplated no significant difference in outcomes between two procedures and an increase cost in laparoscopic surgery..$^{9,10}$

A recent systematic review of meta-analysis of randomized control trials comparing both procedures resulted in a comparable safe and effective treatment of acute appendicitis. Total operation time for this series was longer in laparoscopic group than in conventional open procedure thought to be due to lack of experience
In this Study most of the surgeons performing laparoscopic appendectomy were expert and experienced in laparoscopic procedures. So in our studies longer duration of laparoscopic procedure than open procedure may be explained due to time consumption in insufflation, making ports, and a phase of diagnostic laparoscopy. Length of Hospital stay, which is important for developing countries as it increases overall cost of treatment, was significantly shorter in laparoscopic group $(p=0.015)$ with earlier bowel movements, start and tolerance to oral diet and early discharge from hospital. Thus my study is in alignment with several other researches ${ }^{11,12}$ claiming shorter hospital stay with laparoscopic appendectomy than in open appendectomy.

Pain in our study was analyzed by Visual Analogue scale and tabulation of need of analgesia. To 
overcome psychological factors which may affect result of perception of pain by patients, only number of analgesic doses required were compared in both groups. In this technique both parenteral and oral analgesics use was considerably lower in laparoscopic group due to decreased requirement by patients as shown by some other studies as well. ${ }^{13,14}$

With regards to return to normal activities defined in our study as return to work show promising results for laparoscopic group of patients with mean time of 11.5+-3.1 days in laparoscopic patients and $16.1+-3.3$ days in patients who underwent open appendectomy. Our results are in agreement to study by Helber el $\mathrm{al}^{15}$ and other meta- analysis. ${ }^{16,17}$ No mortality was reported during our research in both groups. A very low mortality rate shown by previous studies of $0.05 \%$ and $0.3 \%$ for laparoscopic and conventional open appendectomy respectively indicate safety of both procedures especially in absence of complicated disease. ${ }^{18}$

In our studies overall postoperative complication was $24.5 \%$ for open and $6.7 \%$ for laparoscopic procedure with most common reported complication of wound dehiscence and wound infection especially in patients who underwent open appendectomy. Wound infection was more commonly observed in patients who had complicated appendicitis. In our research intra operative findings were comparable in both groups with no significant difference in pathology, therefore decrease in post-operative infection in laparoscopic procedure may be explained with minimal contamination of gut and minimal handling of visceras. Conversely intra-abdominal abscess was reported in $4.1 \%$ of patients in laparoscopic group and $0.32 \%$ patients of open appendectomy showing consistent results with other studies that show increase intra-abdominal abscess in laparoscopic group..$^{19,20} \mathrm{~A}$ few possible explanations to this may be an increased bacterial contamination, ${ }^{21,22,23}$ punctilious irrigation further spreading pathogen in whole abdominal cavity without proper suction especially in case of peritonitis $^{24}$, and inadequate leaning curve. ${ }^{25}$
In our study this finding was not statistically significant $(p=0.147)$.

Intra-abdominal abscess is managed with percutaneous drainage as first line therapy or by surgical procedure both covered by antibiotics. Other minor reported complications were vomiting, paralytic ileus, and hemo-peritoneum. Overall cost of laparoscopic procedure was slightly higher. ${ }^{26,27}$

\section{CONCLUSION}

Outcome of Laparoscopic appendectomy is better than open appendectomy in terms of pain and operative duration in patients undergoing Appendectomy.

Copyright (C) 21 Apr, 2017.

\section{REFERENCES}

1. Aarabi S., Sidhwa F., Riehle K. J., Chen Q., Mooney D. P. Pediatric appendicitis in New England: epidemiology and outcomes. Journal of Pediatric Surgery. 2011;46(6):1106-1114.

2. Addiss D. G., Shaffer N., Fowler B. S., Tauxe R. V. The epidemiology of appendicitis and appendectomy in the United States. American Journal of Epidemiology. 1990;132(5):910-925.

3. Bansal S., Banever G. T., Karrer F. M., Partrick D. A. Appendicitis in children less than 5 years old: influence of age on presentation and outcome. The American Journal of Surgery. 2012;204(6):1031-1035.

4. Marzuillo P., Germani C., Krauss B. S., Barbi E. Appendicitis in children less than five years old: a challenge for the general practitioner. World Journal of Clinical Pediatrics. 2015;4(2):19-24.

5. Adwan H., Weerasuriya C. K., Endleman P., Barnes A., Stewart L., Justin T. Laparoscopic versus open appendicectomy in children: a UK District General Hospital experience. Journal of Pediatric Surgery. 2014;49(2):277-279.

6. Svensson J. F., Patkova B., Almström M., Eaton S., Wester T. Outcome after introduction of laparoscopic appendectomy in children: a cohort study. Journal of Pediatric Surgery. 2016;51(3):449-453.

7. Xiao Y., Shi G., Zhang J., et al. Surgical site infection after laparoscopic and open appendectomy: a multicenter large consecutive cohort study. Surgical Endoscopy. 2015;29(6):1384-1393. 
8. Kapischke M., Pries A., Caliebe A. Short term and long term results after open vs. laparoscopic appendectomy in childhood and adolescence: a subgroup analysis. BMC Pediatrics. 2013;13, article 154.

9. Augustin T., Cagir B., VanderMeer T. J. Characteristics of perforated appendicitis: effect of delay is confounded by age and gender. Journal of Gastrointestinal Surgery. 2011;15(7):1223-1231.

10. Groves L. B., Ladd M. R., Gallaher J. R., et al. Comparing the cost and outcomes of laparoscopic versus open appendectomy for perforated appendicitis in children. The American Surgeon. 2013;79(9):861-864.

11. Ohno $\mathrm{Y}$, Morimura $\mathrm{T}$, Hayashi $\mathrm{S}$. Transumbilical laparoscopically assisted appendectomy in children: the results of a single-port, single-channel procedure. Surg Endosc 2012; 26:523-527.

12. Dutta S. Early experience with single incision laparoscopic surgery: eliminating the scar from abdominal operations. J Pediatr Surg 2009; 44:17411745.

13. Codrich D, Scarpa MG, Lembo MA, et al. Transumbilical laparo-assisted appendectomy: a safe operation for the whole spectrum of appendicitis in children-a single-centre experience. Minim Invasive Surg 2013; 2013:216416.

14. Deie K, Uchida H, Kawashima H, et al. Single-incision laparoscopic-assisted appendectomy in children: exteriorization of the appendix is a key component of a simple and cost-effective surgical technique. Pediatr Surg Int 2013; 29:1187-1191.

15. Hellberg A, Rudberg C, Kullmann E,. Prospective randomized multicentre study of laparoscopic versus open appendectomy. Br J Surg. 1999;86:4853.

16. Siewert JR, Schumpelick V, Rothmund M. Gastroenterologische Chirurgie. Springer-Verlag, Berlin, Heidelberg 2011; 3:1052-1053.

17. Sesia SB, Frech M, Häcker FM, et al. Laparoskopische "single port"-appendektomie im kindesalter. Zentralbl Chir 2011; 136:50-55.

18. St Peter SD, Adibe OO, Juang D, et al. Single incision versus standard 3-port laparoscopic appendectomy: a prospective randomized trial. Ann Surg 2011; 254:586-590.
19. Stylianos S, Nichols L, Ventura N, et al. The "all-in-one" appendectomy: quick, scarless, and less costly. J Pediatr Surg 2011; 46:2336-2341.

20. Oltmann SC, Garcia NM, Ventura B, et al. Singleincision laparoscopic surgery: feasibility for pediatric appendectomies. J Pediatr Surg 2010; 45:1208-1212.

21. Stanfill AB, Matilsky DK, KalvakuriK, et al. Transumbilical laparoscopically assisted appendectomy: an alternative minimally invasive technique in pediatric patients. J Laparoendosc Adv Surg Tech A 2010; 20:873-876.

22. Visnjic S. Transumbilical laparoscopically assisted appendectomy in children: high-tech low-budget surgery. Surg Endosc 2008; 22:1667-1671.

23. Kagawa $Y$, Hata S, Shimizu J, et al. Transumbilical laparoscopic-assisted appendectomy for children and adults. Int J Colorectal Dis 2012; 27:411-413.

24. Cobellis G, Torino G, Noviello C, et al. Versatility of one-trocar surgery in children. J Laparoendosc Adv Surg Tech A 2011; 21:549-554.

25. Cheong LH, Emil S. Outcomes of pediatric appendicitis: an international comparison of the United States and Canada. JAMA Surg 2014; 149:5055.

26. Sesia SB, Mayr J, Bruder E, et al. Neurogenic appendicopathy: clinical, macroscopic, and histopathological presentation in pediatric patients. Eur J Pediatr Surg 2013; 23:238-242.

27. Di Saverio S. Emergency laparoscopy: a new emerging discipline for treating abdominal emergencies attempting to minimize costs and invasiveness and maximize outcomes and patients' comfort. J Trauma Acute Care Surg. 2014;77:338-350.

28. Di Saverio S, Mandrioli M, Sibilio A, Smerieri N, Lombardi R, Catena F, Ansaloni L, Tugnoli G, Masetti M, Jovine $E$. A cost-effective technique for laparoscopic appendectomy: outcomes and costs of a casecontrol prospective single-operator study of 112 unselected consecutive cases of complicated acute appendicitis. J Am Coll Surg. 2014;218:e51-e65.

29. Jaschinski T, Mosch C, Eikermann M, Neugebauer EA. Laparoscopic versus open appendectomy in patients with suspected appendicitis: a systematic review of meta-analyses of randomised controlled trials. BMC Gastroenterol. 2015;15:48. 


\title{
PREVIOUS RELATED STUDY
}

Naveed Jabbar, M. Zafar Khan, Aftab Ahmed Ch., LAPAROSCOPIC APPENDICECTOMY; CLIP-CLOSURE OF APPENDIX STUMP (Original) Prof Med Jour 18(2) 233-236 Apr, May, Jun 2011.

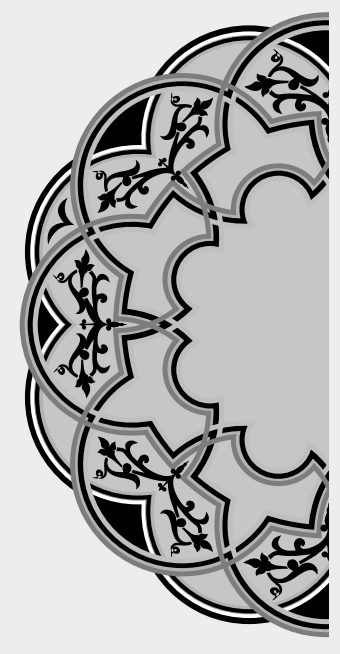

\section{"Behind every great fortune there is a crime."}

\author{
Balzac
}

\section{AUTHORSHIP AND CONTRIBUTION DECLARATION}

\begin{tabular}{|c|l|l|l|}
\hline Sr. \# & \multicolumn{1}{|c|}{ Author-s Full Name } & \multicolumn{1}{|c|}{ Contribution to the paper } & Author=s Signature \\
\hline 1 & Dr. Abdullah Bin Saeed & $\begin{array}{l}\text { Principle investigator } \\
\text { Correspondent Author } \\
\text { Data collection, Analysis \& } \\
\text { Reference collection } \\
2\end{array}$ & $\begin{array}{l}\text { Dr. Ahmad Raees } \\
\text { Research Supervisor }\end{array}$ \\
\hline 3 & Dr. Shoukat Ali & \\
\hline
\end{tabular}

